\title{
Effectiveness of antiretroviral treatment in Colombia
}

\author{
Jorge Enrique Machado-Alba ${ }^{1}$ and Xavier Vidal ${ }^{2}$
}

Suggested citation Machado-Alba JE, Vidal X. Effectiveness of antiretroviral treatment in Colombia. Rev Panam Salud Publica. 2012;32(5):360-7.

\begin{abstract}
Objective. To evaluate the effectiveness of antiretroviral therapies and factors associated with HIVIAIDS control in a population of patients treated by the Colombian Social Security Health System (SGSSS).

Methods. This was a descriptive study of 510 HIV/AIDS patients treated with antiretroviral therapies in 19 cities in Colombia from June 1992-April 2011. Factors assessed from each patient's clinical history were: viral load, CD4 count, antiretroviral treatment regimens, prescribed daily doses of medications, length of disease evolution, duration of therapy, history of opportunistic diseases, and drug costs.

Results. Patients were predominantly male ( $75.1 \%$ males versus $24.9 \%$ women), with a mean age of $41.0 \pm 11.4$ years and an average length of disease progression of 72 months. All recommended treatment regimens were prescribed at the defined daily dose. Treatment was effective in $65.3 \%$ of patients (viral load $<50$ copies per $m L$ ). Non-adherence to treatment, treatment failure, the presence of anxiety or depression, and treatment in the city of Barranquilla were associated with an increased risk of uncontrolled HIV infection. The mean annual cost of drugs per patient was US\$2 736.

Conclusions. Factors associated with uncontrolled HIV infection, especially regarding treatment adherence, must be identified to promote solutions for health care programs treating patients with HIV/AIDS.
\end{abstract}

Key words HIV; acquired immunodeficiency syndrome; antiretroviral therapy, highly active; treatment outcome; Colombia.

Human immunodeficiency virus (HIV) was first detected in the United States in July of 1981. In 1983, the retrovirus was isolated for the first time; a year later, it was clearly demonstrated to be the cause of acquired immunodeficiency syndrome (AIDS) (1, 2). By late 2008, it was estimated that 33.4 million people worldwide had been infected with HIV

\footnotetext{
${ }^{1}$ Grupo Investigación Farmacoepidemiología y Farmacovigilancia, Universidad Tecnológica de Pereira, Pereira, Colombia; and Universitat Autònoma de Barcelona, Barcelona, Spain. Send correspondence to: Jorge Enrique Machado-Alba, email: machado@utp.edu.co.

${ }^{2}$ Universitat Autònoma de Barcelona, Fundación Instituto Catalán de Farmacología, Barcelona, Spain.
}

$(3,4)$. Since the beginning of the HIV/ AIDS epidemic, approximately 13.9 million people have died of the disease $(3,4)$. According to the World Health Organization (WHO), as of 2011 there have been approximately 75620 cases of HIV / AIDS in Colombia (5).

The use of highly active antiretroviral therapy (HAART) has fundamentally altered the course of this disease, decreasing the progression of HIV infection and increasing patient survival (6-12). An estimated 5.2 million people receive antiretroviral therapy worldwide $(3,4)$. Treatment effectiveness is best maintained when using a regimen that is effective and tolerable, thereby allowing adherence to treatment (13). The benefits of HAART may be compromised when certain factors are present, such as defects in host immunity, an increased ability of the virus to develop resistance to drugs, and poor adherence to treatment $(8,10)$. Additionally, these drugs are expensive, exhibit high toxicity, and are not widely accessible in developing countries (11).

The effectiveness of HAART is determined by assessing virological response through viral load measurements, for which results of $<50$ copies $/ \mathrm{mL}$ or undetectable levels indicate an optimal 
response, and by measuring CD4 lymphocyte levels, for which levels $>250$ cells $/ \mathrm{mm}^{3}$ indicate an adequate immune response $(12,14-16)$. The effectiveness of antiretroviral therapies has transformed HIV / AIDS from an inevitably fatal disease to a chronic, treatable condition; however, lack of patient adherence has emerged as the largest barrier to successful therapy and has led to other problems such as poor bioavailability and drug interactions $(16,17)$. In Colombia, a wide range of HAART regimens have been used in patients diagnosed with HIV/AIDS. Many of these treatment regimens do not adhere to preapproved guidelines, and disease management is often adopted empirically due to accessibility issues and the resistance to testing (18).

The present study evaluated the antiretroviral treatments used in HIV / AIDS patients affiliated with the Colombian Social Security Health System (SGSSS) by determining the percentage of patients in whom such treatments were effective. Several factors associated with HIV / AIDS control were also examined: laboratory reference values; sociodemographic data; clinical background; HAART treatment regimens, adherence, and failures; and comorbidities. Lastly, the invoiced cost of the antiretroviral drugs was determined.

\section{METHODS}

This retrospective study of HAART usage considered patients whose HIV positive diagnosis was confirmed by Western blot from 17 June 1992-30 April 2011 and who were affiliated with SGSSS through a health insurance company (EPS) in the cities of Armenia, Barranquilla, Bogotá, Bucaramanga, Cali, Cartagena, Cúcuta, Girardot, Ibagué, Manizales, Medellín, Montería, Neiva, Pereira, San José de Guaviare, Santa Marta, Sincelejo, Villavicencio, and Valledupar. The study group included all patients who had ever undergone HAART, including those who died, discontinued therapy, were lost to follow-up, or did not undergo viral load measurements.

Data on each patient was obtained by a physician who used a designated data collection form to systematically collect and record the study variables from each medical record (Table 1). Each patient's complete medical records for the 6 months prior to 30 April 2011 were analyzed to determine the prescription regimen's effectiveness. Medical records were organized according to each EPS and updated with each patient's follow-up information per the treatment records of the HIV/AIDS program.

The protocol was reviewed by the Bioethics Committee of the Universidad Tecnológica of Pereira (Pereira, Colombia); it was approved as "research without risk" and guaranteed the anonymity of the patients.

\section{Data analysis}

Data analysis was performed using IBM SPSS Statistics software, version 19 Illinois, United States). The descriptive statistics used were mean, standard deviation, minimum and maximum values for continuous variables, and percentages for categorical variables. Chi-squared test was used to compare categorical variables. The mean differences between the first and last values (SPSS Inc., an IBM company, Chicago,

of interest were determined using a nonparametric paired test (Wilcoxon test) because of the asymmetry of the distributions. Binary logistic regression models were applied using infection control as the dependent variable. Statistical significance was predetermined to be $P<0.05$ (95\% confidence interval).

\section{RESULTS}

The study population was composed of 510 HIV-positive patients undergoing antiretroviral treatment at the start of the study period in the 19 cities. Table 2 shows the study population's characteristics. The 510 patients were predominantly male (3:1), with a mean age of 41 \pm 11.4 years.

The HIV prevalence rate was 0.36 per 10000 inhabitants. The mean duration of illness was 72.8 months (range: $11-272$ months) as of 30 April 2011. The mean duration of treatment was 63.4 months (range: 0-214 months), and the time between diagnosis and treatment initiation varied from $0-132$ months.

TABLE 1. Study variables collected from the medical records of 510 HIV/AIDS patients treated by the HIV/AIDS program of the Social Security Health System in 19 cities, Colombia, 1992-2011

\begin{tabular}{|c|c|c|}
\hline Category & & Variable \\
\hline Sociodemographic data & a) & Age, b) sex, c) marital status (single or married) \\
\hline \multirow[t]{4}{*}{ Clinical background } & a) & $\begin{array}{l}\text { Previous diagnosis of opportunistic diseases: tuberculosis, cryptococcosis, } \\
\text { histoplasmosis, candidiasis, toxoplasmosis, pneumocystis, or molluscum } \\
\text { contagiosum }\end{array}$ \\
\hline & b) & $\begin{array}{l}\text { Other sexually-transmitted diseases (STDs): condylomatosis, syphilis, } \\
\text { genital herpes, or blennorrhagia }\end{array}$ \\
\hline & c) & Number of STDs \\
\hline & d) & History of psychoactive substance use \\
\hline \multirow[t]{4}{*}{ Laboratory reference values } & a) & First, annual, and last viral load (in copies $/ \mathrm{mL}$ ) \\
\hline & & Controlled: viral load < 50 copies $/ \mathrm{mL}$ \\
\hline & b) & First, annual, and last CD4 counts (in cells $/ \mathrm{mm}^{3}$ ) \\
\hline & & Adequate immune response: CD4 counts $>250 / \mathrm{mm}^{3}$ \\
\hline \multirow[t]{8}{*}{ Pharmacological } & a) & Treatment regimens of antiretroviral drugs, doses \\
\hline & b) & Time duration of antiretroviral treatment \\
\hline & c) & Number of antiretroviral pills taken per day \\
\hline & d) & Number of doses per day of antiretroviral treatment \\
\hline & e) & Report of treatment failure \\
\hline & f) & Recorded treatment modifications \\
\hline & g) & $\begin{array}{l}\text { Report of any antiretroviral drug intolerance, drug name, and type of side } \\
\text { effect }\end{array}$ \\
\hline & h) & Report of non-adherence \\
\hline \multirow[t]{5}{*}{ Clinical } & a) & Evolution time of the disease \\
\hline & b) & Time between diagnosis and initiation of antiretroviral therapy \\
\hline & c) & $\begin{array}{l}\text { Comorbidities, treatment received for these, and number of additional } \\
\text { medications used to treat these conditions }\end{array}$ \\
\hline & d) & Diagnosis of anxiety or depression during the course of treatment \\
\hline & e) & $\begin{array}{l}\text { Evidence of hospitalizations due to HIV/AIDS, the associated } \\
\text { complications, and the number of such admissions }\end{array}$ \\
\hline \multirow[t]{2}{*}{ Antiretroviral drug cost } & a) & Mean cost of antiretroviral drugs per month per patient ${ }^{a}$ \\
\hline & b) & Cost per 1000 inhabitants per daya \\
\hline
\end{tabular}

a Exchange rate on 30 April 2011: US $\$ 1=1813$ Colombian pesos. 
TABLE 2. Sociodemographic and clinical characteristics of 510 HIV/AIDS patients treated by the HIV/AIDS program of the Social Security Health System in 19 cities, Colombia, 1992-2011

\begin{tabular}{|c|c|c|}
\hline Characteristic & No. ${ }^{a}$ & $\%^{a}$ \\
\hline Age $(\mu \pm$ years old $)$ & 41.0 & 11.4 \\
\hline Gender (female/male) & $127 / 383$ & $24.9 / 75.1$ \\
\hline Marital status (single/married) & $215 / 295$ & $42.2 / 57.8$ \\
\hline Onset of illness ( $\mu\left[S D^{b}\right]$, months) & 72.8 & 44.2 \\
\hline Diagnosis-onset latency time HAART ( $\mu \pm \mathrm{SD}$, months) & 9.2 & 17.8 \\
\hline Average treatment onset ( $\mu[S D]$, months) & 63.4 & 38.4 \\
\hline Couple having HIV (yes/no) & $164 / 346$ & $32.2 / 67.8$ \\
\hline \multicolumn{3}{|l|}{ History of opportunistic diseases } \\
\hline Candidiasis & 162 & 31.8 \\
\hline Pneumocystis & 91 & 17.8 \\
\hline Herpes varicella zoster & 91 & 17.8 \\
\hline Toxoplasmosis & 57 & 11.2 \\
\hline Tuberculosis & 45 & 8.8 \\
\hline Cryptococcosis & 10 & 2.0 \\
\hline Molluscum contagiosum & 8 & 1.6 \\
\hline Histoplasmosis & 7 & 1.4 \\
\hline \multicolumn{3}{|l|}{ History of sexually-transmitted diseases } \\
\hline Condylomatosis & 66 & 12.9 \\
\hline Syphilis & 64 & 12.5 \\
\hline Genital herpes & 55 & 10.8 \\
\hline Gonorrhea & 39 & 7.6 \\
\hline \multicolumn{3}{|l|}{ Comorbidities } \\
\hline Anxiety or depression & 186 & 36.5 \\
\hline Dyslipidemia & 68 & 13.3 \\
\hline Neurologic sequelae by opportunistic pathogens & 51 & 10.0 \\
\hline Peptic ulcer disease & 48 & 9.4 \\
\hline Arterial hypertension & 48 & 9.4 \\
\hline Rhinitis, sinusitis & 30 & 5.9 \\
\hline Chronic diarrhea & 20 & 3.9 \\
\hline Hepatitis B & 17 & 3.3 \\
\hline
\end{tabular}

a Unless otherwise specified.

${ }^{\mathrm{b}}$ Standard deviation.

Many of the patients had a history of illnesses caused by opportunistic pathogens, particularly Candida albicans and Pneumocystis jiroveci. A total of 38 patients $(7.4 \%)$ had at least two additional STDs.

The most common comorbidities found in the patients are shown in Table 2. A diagnosis of anxiety or depression was the most frequently reported problem and was associated with a significant lack of HIV infection control $(P=0.036)$. At the end of the data collection period, a total of $337(66.1 \%)$ patients were receiving treatment for some other condition. Only $4.7 \%$ of patients admitted consuming psychoactive substances.

\section{Antiretroviral treatment}

The antiretroviral drugs most frequently used and the treatment regimens employed are shown in Tables 3 and 4, respectively. All drugs were ad-

\section{Hospitalization}

The study also found that 216 patients $(42.3 \%)$ had a history of hospitalization due to HIV or associated complications. Of these 216 patients, 161 cases $(74.5 \%$ of egress) had been hospitalized once, $37(17.1 \%)$ had been hospitalized twice, and $15(6.9 \%)$ had been hospitalized three times.

\section{Treatment noncompliance}

Reports of noncompliance were found in 198 treatment cases $(38.8 \%$ of patients); these patients notified the attending physician that they were not taking the therapy for a variety of reasons (e.g., lack of adherence, voluntary resignation after losing their affiliation with the SGSSS, or ignorance). There were also reports of therapeutic failure in 135 cases $(26.5 \%)$, which led to reconsideration of the patient's treatment. Finally, adverse drug reactions were reported in 163 patients (32.0\%), most important of which were dyslipidemia ( $n=76,14.9 \%)$, gastrointestinal intolerance $(n=47,9.2 \%)$, anemic syndrome $(n=36,7.1 \%)$, lipodystrophy $(n=21$, $4.1 \%)$, nightmares $(n=19,3.7 \%)$, allergic reactions ( $n=14,2.7 \%)$, elevated liver enzymes $(n=11,2.2 \%)$, depression $(n=$ $10,2.0 \%)$, peripheral neuropathy $(n=7$, $1.4 \%)$, and urolithiasis $(n=6,1.2 \%)$.

\section{Viral load measurements}

Viral load was measured at diagnosis in 349 of the 510 cases $(68.4 \%)$ and within the 6 months prior to data collection, in 484 cases $(94.9 \%)$. However, 303 patients (59.4\%) underwent a mean of 7 viral load measurements over the course of the disease, which on average was 6 years. The percentage of patients with an initial and last viral load below 50 copies/mL is shown in Figure 1.

It was established that antiretroviral therapy was still effective in 316 patients $(65.3 \%)$. The mean baseline viral load was 138021 copies/mL (SD: 265 437; range: 39-2 089 296), and the last recorded viral load was 9867 copies/ $\mathrm{mL}$ (SD: 67 710; range: undetectable1292 442). Using nonparametric tests (Wilcoxon test), significant differences were found between the mean initial and last viral load $(P<0.001)$.

\section{CD4 measurements}

CD4 measurements were conducted at diagnosis in 349 of the 510 cases (68.4\%), and during the 6 months prior to the study period in 484 cases $(94.9 \%)$. The percentages of patients with initial and 
TABLE 3. Prescription patterns of most frequently-used antiretroviral drugs for 510 HIV/AIDS patients treated by the Social Security Health System in 19 cities, Colombia, 1992-2011

\begin{tabular}{lccccc}
\hline \multicolumn{1}{c}{ Drug } & $\begin{array}{c}\text { Number of } \\
\text { patients }\end{array}$ & $\begin{array}{c}\text { Usage } \\
(\%)\end{array}$ & $\begin{array}{c}\text { Mean dose } \\
\text { (mg/day) }\end{array}$ & $\begin{array}{c}\text { Dose range } \\
\text { (mg/day) }\end{array}$ & Mean age \\
\hline Lamivudine & 452 & 88.6 & 300 & $300-300$ & 40.6 \\
Zidovudine & 328 & 64.3 & 600 & $600-600$ & 31.3 \\
Efavirenz & 239 & 46.9 & 600 & $600-600$ & 42.0 \\
Abacavir & 157 & 30.8 & 600 & $600-600$ & 44.9 \\
Lopinavir/ritonavir & 147 & 28.8 & $80 / 200$ & $200-800 / 100-200$ & 41.6 \\
Didanosine & 63 & 12.4 & 400 & $400-400$ & 40.8 \\
Ritonavir & 48 & 9.4 & 150 & $100-200$ & 43.4 \\
Atazanavir & 45 & 8.8 & 400 & $300-600$ & 40.0 \\
Nevirapine & 37 & 7.3 & 400 & $400-400$ & 39.0 \\
Estavudine & 25 & 4.9 & 80 & $80-120$ & 44.6 \\
\hline
\end{tabular}

TABLE 4. Most frequently-used treatment regimens for 510 HIV/AIDS patients treated by the Social Security Health System in 19 cities, Colombia, 2011

\begin{tabular}{lcc}
\hline \multicolumn{1}{c}{ Combination of antiretroviral drugs } & Frequency & $\%$ \\
\hline Lamivudine/Zidovudine + Efavirenz & 155 & 30.3 \\
Lamivudine/Zidovudine + Lopinavir/Ritonavir & 75 & 14.7 \\
Lamivudine + Abacavir + Efavirenz & 32 & 6.3 \\
Lamivudine + Abacavir + Lopinavir/Ritonavir & 28 & 5.5 \\
Lamivudine/Zidovudine + Abacavir & 27 & 5.3 \\
Lamivudine/Zidovudine + Nevirapine & 24 & 4.7 \\
Abacavir + Didanosine + Lopinavir/Ritonavir & 18 & 3.5 \\
Lamivudine +Atazanavir + Didanosine & 13 & 2.5 \\
Lamivudine + Estavudine + Efavirenz & 9 & 1.8 \\
Lamivudine + Didanosine + Lopinavir/Ritonavir & 8 & 1.6 \\
Lamivudine/Zidovudine + Abacavir + Efavirenz & 6 & 1.2 \\
Lamivudine + Didanosine + Efavirenz & 6 & 1.2 \\
Others combinations & 52 & 19.4 \\
\hline
\end{tabular}

FIGURE 1. Distribution of patients having viral load and CD4 lymphocyte measurements treated by the HIV/AIDS program of Social Security Health System in 19 cities, Colombia, 1992-2011
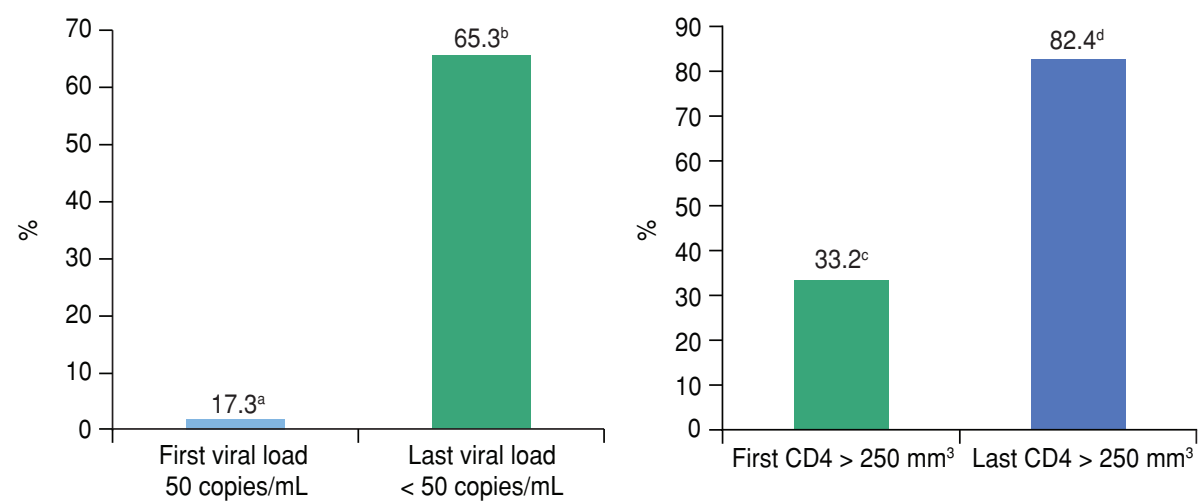

a Data reported from 6 / 349 patients.

${ }^{b}$ Data reported from $316 / 484$ patients.

c Data reported from 116 / 349 patients.

d Data reported from 395 / 484 patients.

last CD4 levels above 250 cells $/ \mathrm{mm}^{3}$ are shown in Figure 1.

An adequate immunologic response to antiretroviral therapy was observed in 399 patients (82.4\% of cases) at the time of data collection. The mean initial CD4 measurement was 216.4 cells $/ \mathrm{mm}^{3}$ was found between the last viral load in the range of controlled infections and the last CD4 lymphocyte count in the range of adequate immune response in 288 of 316 cases $(91.1 \%)(P<0.001)$.

\section{Controlled versus uncontrolled patients}

Table 5 presents the bivariate analysis results for comparing the subgroup of patients whose HIV infection was controlled to the subgroup with uncontrolled infections. No statistical association was found between a lack of HIV infection control and any of these variables: gender, marital status, HIVpositive partner, history of opportunistic diseases or STDs, the number of daily dosage intervals, the duration between the diagnosis of infection and antiretroviral treatment initiation, time to disease progression, changes in treatment over the course of the disease, treatment for comorbidities, report of intolerance to antiretroviral drugs, psychoactive substance use, or hospitalizations for complications associated with the disease. There was a significant association between HIV control and these specific variables: a Lamivudine/Zidovudine + Efavirenz and Didanosine + Abacavir + Lopinavir/Ritonavir regimens, as well as dyslipidemia, lack of adherence to antiretroviral therapy, number of pills taken per day, treatment failure, depression or anxiety, age, treatment costs $<$ US\$ 275, and the patient's hometown.

In patients reporting treatment failure, the viral load values entered the controlled range for $52.6 \%$ of them once a new treatment regimen was established. In patients with intolerance, once the regimen was modified, their values were controlled in $69.6 \%$ of cases. It was observed that these patients had to take four or more pills per day ( $P=$ 0.002) spread out over three or more daily doses $(P=0.01)$. In addition, patients who reported either therapeutic failure $(P<0.001)$, need for regimen modification $(P<0.001)$, psychoactive substance use $(P=0.015)$, or the presence of anxiety or depression $(P=0.002)$ were significantly associated with the possibility that they had not adhered to the treatment regimen.

The dependent variable for the multivariate analysis was uncontrolled HIV (viral load greater than 50 copies $/ \mathrm{mL}$ ), and the covariates were those variables 
TABLE 5. Bivariate analysis of the sociodemographic, clinical, and pharmacological characteristics of HIV/AIDS patients ${ }^{\text {a }}$ treated by the Social Security Health System in 19 cities, Colombia, 1992-2011

\begin{tabular}{|c|c|c|c|c|c|c|c|c|}
\hline \multirow[b]{2}{*}{ Variable } & \multicolumn{2}{|c|}{$\begin{array}{l}\text { Controlled } \\
\text { HIV/AIDS }^{\mathrm{b}}\end{array}$} & \multicolumn{2}{|c|}{$\begin{array}{l}\text { Not controlled } \\
\text { HIV/AIDS }\end{array}$} & \multirow[b]{2}{*}{$P$-value ${ }^{\mathrm{c}}$} & \multirow[b]{2}{*}{$\mathrm{RR}^{\mathrm{d}}$} & \multicolumn{2}{|c|}{$95 \% \mathrm{Cl}$} \\
\hline & $(n=316)$ & $\%$ & $(n=168)$ & $\%$ & & & lower & upper \\
\hline \multicolumn{9}{|l|}{ Treatment regimens } \\
\hline \multicolumn{8}{|l|}{ Lamivudine/Zidovudine + } & 2.537 \\
\hline \multicolumn{9}{|l|}{ Abacavir + Didanosine + } \\
\hline \multicolumn{8}{|l|}{ Lamivudine/Zidovudine + } & 1.531 \\
\hline \multicolumn{9}{|l|}{ Lamivudine + Abacavir + } \\
\hline \multicolumn{9}{|l|}{ Lamivudine + Abacavir + } \\
\hline \multicolumn{9}{|l|}{ Lamivudine/Zidovudine + } \\
\hline \multicolumn{8}{|l|}{ Lamivudine/Zidovudine + } & 1.581 \\
\hline \multicolumn{9}{|l|}{ Adverse reactions } \\
\hline Gastric intolerance & 19 & 67.9 & 9 & 32.1 & 0.768 & 1.1 & 0.500 & 2.556 \\
\hline Dyslipidemia & 26 & 83.9 & 5 & 16.1 & 0.024 & 2.9 & 1.101 & 7.758 \\
\hline Anemic syndrome & 24 & 75.0 & 8 & 25.0 & 0.232 & 1.6 & 0.722 & 3.744 \\
\hline Lipodystrophy & 11 & 84.6 & 2 & 15.4 & 0.137 & 3.0 & 0.656 & 13.665 \\
\hline Allergy & 6 & 66.7 & 3 & 33.3 & 0.93 & 1.1 & 0.263 & 4.311 \\
\hline Liver enzyme elevation & 6 & 75.0 & 2 & 25.0 & 0.56 & 1.6 & 0.321 & 8.048 \\
\hline Urolithiasis & 6 & 100.0 & 0 & 0.0 & 0.072 & 0.6 & 0.607 & 0.693 \\
\hline \multicolumn{9}{|l|}{ Number of pills/day } \\
\hline$\leq 3$ & 135 & 71.1 & 55 & 28.9 & 0.032 & 0.6 & 0.441 & 0.966 \\
\hline$\geq 4$ & 181 & 61.6 & 113 & 38.4 & & & & \\
\hline \multicolumn{9}{|l|}{ Number of doses/day } \\
\hline$\leq 2$ & 264 & 67.1 & 130 & 32.9 & 0.097 & 0.6 & 0.422 & 1.076 \\
\hline$\geq 3$ & 52 & 57.7 & 38 & 42.3 & & & & \\
\hline \multicolumn{9}{|l|}{ Nonadherence report } \\
\hline Adherent & 218 & 73.1 & 80 & 26.9 & $<0.001$ & 0.4 & 0.278 & 0.601 \\
\hline Non adherent & 98 & 52.6 & 88 & 47.4 & & & & \\
\hline \multicolumn{9}{|l|}{ Therapeutic failure report } \\
\hline Yes & 70 & 52.6 & 63 & 47.4 & & & & \\
\hline No & 246 & 70.1 & 105 & 29.9 & $<0.001$ & 0.4 & 0.315 & 0.715 \\
\hline \multicolumn{9}{|l|}{$\begin{array}{l}\text { Report of anxiety or } \\
\text { depression }\end{array}$} \\
\hline Yes & 105 & 59.3 & 72 & 40.7 & & & & \\
\hline No & 211 & 68.7 & 96 & 31.3 & 0.036 & 0.6 & 0.452 & 0.975 \\
\hline Age (years) & & & & & & & & \\
\hline$<19$ & 3 & 30.0 & 7 & 70.0 & 0.018 & 0.2 & 0.056 & 0.864 \\
\hline $19-59$ & 298 & 66.6 & 149 & 33.4 & 0.027 & 2.1 & 1.076 & 4.142 \\
\hline$\geq 60$ & 15 & 55.5 & 12 & 44.5 & 0.274 & 0.6 & 0.296 & 1.418 \\
\hline City & & & & & & & & \\
\hline Barranquilla & 52 & 49.5 & 53 & 50.5 & $<0.001$ & 0.4 & 0.275 & 0.664 \\
\hline Medellín & 65 & 75.5 & 21 & 24.5 & 0.027 & 1.8 & 1.064 & 3.087 \\
\hline Manizales & 35 & 72.9 & 13 & 27.1 & 0.242 & 1.4 & 0.763 & 2.891 \\
\hline Pereira & 13 & 81.2 & 3 & 18.8 & 0.173 & 2.3 & 0.663 & 8.400 \\
\hline Cost of treatment (US\$) & & & & & & & & \\
\hline$<275^{\mathrm{e}}$ & 256 & 67.5 & 123 & 32.5 & 0.047 & 1.6 & 1.003 & 2.429 \\
\hline $275-551$ & 39 & 59.1 & 27 & 40.9 & 0.255 & 0.7 & 0.432 & 1.250 \\
\hline$>551$ & 21 & 53.8 & 18 & 46.2 & 0.117 & 0.6 & 0.307 & 1.147 \\
\hline Time to regimen change & & & & & & & & \\
\hline$<1$ year & 118 & 63.1 & 69 & 36.9 & 0.422 & 0.9 & 0.583 & 1.254 \\
\hline $1-2$ years & 60 & 65.2 & 32 & 34.8 & 0.987 & 1.0 & 0.618 & 1.605 \\
\hline$>2$ years & 5 & 55.6 & 4 & 44.4 & 0.535 & 0.7 & 0.175 & 2.488 \\
\hline
\end{tabular}

a Data reported from 484 patients.

${ }^{b}$ Level of viral load $<50$ copies $/ \mathrm{mL}$

${ }^{c}$ Based on the chi-square test.

${ }^{\mathrm{d}}$ Risk Ratio.

e Exchange rate on 30 April 2011: US\$1 = 1813 Colombian pesos. significantly associated with the bivariate analysis. The binary logistic regression model revealed that the independent variables associated with the risk of uncontrolled HIV were non-adherence to therapy (odds ratio [OR]: 2.16 ; $95 \%$ confidence interval [95\% CI]: 1.434-3.283; $P<0.001)$; report of treatment failure (OR: 1.87; 95\%CI: 1.172-2.993; $P=0.009$ ); report of anxiety or depression (OR: 1.55; 95\%CI: 1.018-2.365; $P=0.041$ ); and treatment in the city of Barranquilla (OR: 2.5; 95\%CI: 1.538-4.063; $P<0.001)$.

\section{Cost evaluation}

The mean cost of antiretroviral drugs per month per patient was US\$ 228 (range: US\$ 39-US\$ 4 850). The mean cost of drugs per patient per year was US\$ 2736 (range: US\$ 467-US\$ 58 197). The total cost per year of therapy for all patients was US\$ 1395523 ; the cost per 1000 inhabitants per day was US\$2.80.

\section{DISCUSSION}

The control of HIV infection is a global concern. According to different reports from around the world, the number of controlled patients receiving antiretroviral therapy varies from $25.0 \%-84.0 \%$ $(12,15,16,19,20)$. The use of inadequate treatment regimens, insufficient dosing, and especially, non-adherence to management are the most frequent and important reasons that have been associated with the inability to control infection (17).

Of the patients in this study, $65.3 \%$ exhibited controlled viral load values which, when compared with control rates from other countries, ranks as "intermediate" control $(14,16,19,20)$. The significant difference between the mean initial viral load and the last recorded level supports the effectiveness of these treatments. The correlation between an adequate immune response as evidenced by CD4 cell counts greater than 250 cells $/ \mathrm{mm}^{3}$ and a low viral load suggests that the initial therapy was effective in these patients $(12,15,16)$. However, one-third of the patients did not achieve the treatment goals and had a significant risk of increased morbidity, hospitalizations, and even mortality. A reduction in viral load reduces transmission and may reduce the incidence of new infections (21), but viral load suppression depends on consistent administration of HAART. 
The increased risk of uncontrolled HIV is associated with the inability to suppress viral load, which leads to resistance and treatment failure (22).

The usage frequency of the various antiretroviral drugs and treatment regimens is similar to that reported by previous research $(18,23)$. The present study also confirmed the previously-assessed effectiveness of the HAART guidelines, which state that all patients should receive drugs with high intrinsic value, the appropriate DDD, and effective combinations. Lamivudine-Zidovudine + Efavirenz was the most frequent and most effective treatment and is suggested as one of the first options in the Clinical Practice Guidelines for HIV/AIDS in Colombia and in the Strategies for Management of Antiretroviral Therapy Study Group study (SMART) $(14,24)$.

Additionally, the present study demonstrated that this regimen was associated with higher rates of controlled infections and reduced the frequency of intolerance and treatment failure (12, $24,25)$. The pattern of use for this regimen is $30.3 \%$, which must be placed in context considering that most doctors are subject to national and international recommendations for their patients' initial course of therapy. However, a growing number of patients are being prescribed Abacavir, which WHO recommends as the first choice for HIV/ AIDS treatment (3).

The present study found that in these 19 cities in Colombia, 64 different combinations of antiretrovirals were being used to treat patients, raising the questions: What criteria are being followed for the implementation of treatment regimens? What reliable scientific information supports and guides these regimens? What percentage of these regimens fall outside of the recommended national and global guidelines? $(23,26)$. As the selection of drugs broadens, physicians must consider tolerability, toxicity, resistance tests, number of pills per day, number of daily doses, interactions, comorbidities, and even, patient preferences (17).

The present study also found multiple risk factors that affected patient health, in particular a history of opportunistic diseases, including candidiasis, pneumocystosis, and toxoplasmosis, as show by another study (27); however, tuberculosis was not the most frequent, as it was in another country ( $8.9 \%$ vs $22.4 \%$ )
(28). As would be expected, determining the HIV status of individuals who present these opportunistic infections and initiating antiretroviral therapy early if HIV-positive are associated with reduced mortality (17). Of note is the significant number of cases with a history of other STDs, especially genital herpes, genital warts, and syphilis, which can be related to sexual behaviors, a sense of vulnerability, and the patient's tendency towards self protection.

No association was found between the virological control of HIV infection and the following variables: age, gender, marital status, history of opportunistic diseases, number of daily dosing intervals, number of STDs acquired, intolerance to drugs, number of drugs, comorbidity management, or number of hospitalizations, contrary to the findings of others (17, 18, 29). However, a significant association was found between poor control of viral load and each of the following: reporting of non-adherence to treatment, therapeutic failure, number of pills daily, report of anxiety or depression, and the city where the patient was being treated, as established by other studies $(17,18,23,29,30)$.

The finding that some patients had not had viral loads and CD4 levels measured at baseline (31.6\% of patients) indicates that clinicians may be failing to order the testing imperative to devising the most effective treatment plan $(12,31$, 32). This is especially relevant given that evidence shows early therapy initiation is associated with mortality reduction of up to $94 \%$ (17). Furthermore, finding that, in the 6 months prior to the study, $94.9 \%$ of patients reported both viral load and CD4 counts shows that use of these tests has increased dramatically, an observation supported by an earlier study (18).

Treatment adherence is one of the most important factors for ensuring effectiveness; however, in the present study, over one-third of patients had problems maintaining continuity of therapy for any period. Previous studies have identified multiple factors associated with failure to take prescribed medication, i.e., "potential barriers," including personal motivation, support systems, the patient's organizational skills, the health service provider, and whether the therapy is convenient and well tolerated $(22,29,30)$. It must be acknowledged that in Colombia, ad- herence to treatment can be influenced by alcohol consumption, psychoactive substance use, the perceived stigma of being HIV-positive, and loss of employment, which jeopardizes affiliation with the SGSSS (18). Certain measures can improve adherence and may address recognized barriers, such as treating the patient's depression or other mental illness, identifying in advance the use of psychoactive drugs, and if possible, providing a once-a-day regimen with as few pills as possible (22).

The toxicity associated with the use of antiretrovirals is an obvious problem that often affects adherence to treatment and requires regimen replacement (12, 19). The fact that approximately $32 \%$ of patients presented with undesirable side-effects should elicit the development of better-tolerated alternatives. This study found that, in particular, dyslipidemia and a heightened risk of atherosclerosis, which then increases cardiovascular risk, were the main problems associated with HIV treatment; additionally, anemia, lipodystrophy, peripheral neuropathy, and urolithiasis were present, as observed in other countries $(3,12,19,33,34)$.

It is also important to recognize the potential comorbidities that can be present in these patients, including dyslipidemia and neurological sequelae resulting from opportunistic infections. Use of effective and tolerable treatments to avoid these complications can positively impact quality of life and life expectancy. A patient whose illness is well-managed can live up to an estimated 39 years following HIV diagnosis (22).

The reported treatment failure of $26.5 \%$ is higher than that observed by others and may be related to nonadherence to $\operatorname{HAART}(12,18,19)$. In all cases of failure, identifying the drug to which the patient is resistant is essential for guiding therapy (35). Patients who become resistant require more complex and costly treatment regimens (22).

The direct cost of antiretroviral therapy was less than that reported for high-income countries (US\$ $19400-$ US\$ 23100 per patient per year), but was in the range of low-income countries (US\$ 350-US\$ 10 000). Additionally, less expensive treatment regimens were associated with a lower risk of treatment failure. The SGSSS must evaluate how much it can contribute to managing the health of HIV-infected patients and how 
much should be invested in programs focused on HIV prevention (36).

\section{Study limitations}

Because the sample came from an SGSSS-affiliated population, the results cannot be generalized to groups with different epidemiological characteristics. Furthermore, the study data were obtained from the medical records of patients from different cities, so there is no assurance that standardized techniques were used to measure the laboratory parameters.

\section{Conclusions}

According to the study results, $34.7 \%$ of patients had uncontrolled HIV/AIDS. The prevalent features of these cases were a history of poor adherence to therapy, treatment failure, a diagnosis of anxiety or depression, and treatment in the city of Barranquilla. The above findings suggest that health care programs for HIV patients should initiate measures to promote greater adherence; facilitate continuous access to HAART, even if a patient's SGSSS membership

\section{REFERENCES}

1. Masur H, Michelis MA, Greene JB, Onorato I, Stouwe RA, Holzman RS, et al. An outbreak of community-acquired Pneumocystis carinii pneumonia: initial manifestation of cellular immune dysfunction. N Engl J Med. 1981;305:1431-8.

2. Beyrer C, Mayer KH. HIV epidemiology update and transmission factors: risks and risk contexts-16th International AIDS Conference epidemiology plenary. Clin Infect Dis. 2007;44:981-7.

3. World Health Organization, United Nations. Epidemic update and health sector progress towards universal access. WHO, UNICEF, UNAIDS progress report 2011: global HIV/AIDS response. Available from http:/ / whqlibdoc.who.int/publications / 2011/9789241502986_eng.pdf Accessed on 7 March 2012.

4. Simon V, Ho DD, Abdool Karim Q. HIV/ AIDS epidemiology, pathogenesis, prevention, and treatment. Lancet. 2006;368:489-504.

5. Ministerio de Protección Social. Seguimiento de la Declaración de compromiso sobre el VIH/SIDA, Informe UNGASS-2012. Colombia 2012. Available from http://www.un aids.org/en/dataanalysis/monitoringcoun tryprogress/progressreports/2012countries/ ce_CO_Narrative_Report[1].pdf Accessed on 23 April 2012.

6. Hammer SM. Clinical practice. Management of newly diagnosed HIV infection. N Engl J Med. 2005;353:1702-10.

7. Wegbreit J, Bertozzi S, DeMaria LM, Padian NS. Effectiveness of HIV prevention strategies in resource-poor countries: tailoring the intervention to the context. AIDS. 2006;20:1217-35.

8. Clavel F, Hance AJ. HIV drug resistance. N Engl J Med. 2004;350:1023-35.

9. Powderly WG, Landay A, Lederman MM. Recovery of the immune system with antiretroviral therapy: the end of opportunism? JAMA. 1998;280:72-7.

10. Murphy EL, Collier AC, Kalish LA, Assmann SF, Para MF, Flanigan TP, et al.; Viral Activation Transfusion Study Investigators. Highly active antiretroviral therapy decreases mortality and morbidity in patients with advanced HIV disease. Ann Intern Med. 2001;135:17-26.
11. D'Amato RM, D'Aquila RT, Wein LM. Management of antiretroviral therapy for HIV infection: modelling when to change therapy. Antivir Ther. 1998;3:147-58.

12. Ministerio de Protección Social. Guía para el manejo del VIH/SIDA basada en la evidencia. Bogotá, Colombia: Diario Oficial; 2006: 245-57.

13. Sethi AK, Celentano DD, Gange SJ, Moore $\mathrm{RD}$, Gallant JE. Association between adherence to antiretroviral therapy and human immunodeficiency virus drug resistance. Clin Infect Dis. 2003;37:1112-8.

14. Potard V, Rey D, Mokhtari S, Frixon-Marin V, Pradier C, Rozenbaum W, et al.; Firstline highly active antiretroviral regimens in 2001-2002 in the French hospital database on HIV: combination prescribed and biological outcomes. Antivir Ther. 2007;12:317-24.

15. Green H, Gibb DM, Walker AS, Pillay D, Butler K, Candeias F, et al; Paediatric European Network for the Treatment of AIDS. Lamivudine/abacavir maintains virological superiority over zidovudine/lamivudine and zidovudine/abacavir beyond 5 years in children. AIDS. 2007;21:947-55.

16. Bartlett JA, Fath MJ, Demasi R, Hermes A, Quinn J, Mondou E, et al. An updated systematic overview of triple combination therapy in antiretroviral-naive HIV-infected adults. AIDS. 2006;20:2051-64.

17. Atkinson MJ, Petrozzino JJ. An evidence-based review of treatment-related determinants of patients' nonadherence to HIV medications. AIDS Patient Care STDS. 2009;23:903-14.

18. Machado-Alba JE, González-Santos DM, Vidal-Guitart X. Effectiveness of antiretroviral treatment in patients from Pereira and Manizales. Rev Salud Publica (Bogota). 2011;13:492-503.

19. Hammer SM, Eron JJ Jr, Reiss P, Schooley RT, Thompson MA, Walmsley S, et al.; International AIDS Society (United States). Antiretroviral treatment of adult HIV infection: 2008 recommendations of the International AIDS Society-USA panel. JAMA. 2008;300:555-70.

20. Barth RE, van der Meer JT, Hoepelman AI, Schrooders PA, van de Vijver DA, Geelen $\mathrm{SP}$, et al. Effectiveness of highly active anti- status changes; actively seek those who are complying with health checkups; and use patient education to promote greater compliance.

Additionally, clinicians should order blood work periodically to determine immune response and monitor therapy effectiveness. Finally, less expensive HAART regimens were associated with reduced risk of therapeutic failure, so clinicians should prescribe the least expensive options that do not compromise effectiveness. retroviral therapy administered by general practitioners in rural South Africa. Eur J Clin Microbiol Infect Dis. 2008;27:977-84.

21. Thompson MA, Aberg JA, Cahn P, Montaner JS, Rizzardini G, Telenti A, et al.; International AIDS Society-USA. Antiretroviral treatment of adult HIV infection: 2010 recommendations of the International AIDS Society-USA panel. JAMA. 2010;304:321-33.

22. Enriquez M, McKinsey D. Strategies to improve HIV treatment adherence in developed countries: clinical management at the individual level. HIV/AIDS (Auckl). 2011; 3:45-51.

23. Machado JE, Alzate JA. Patrones de prescripción de antirretrovirales en 997 pacientes colombianos. Biomedica. 2008;28:78-86.

24. Strategies for Management of Antiretroviral Therapy Study Group. CD4+ count-guided interruption of antiretroviral treatment. N Engl J Med. 2006;355:2283-96.

25. Shafer RW, Smeaton LM, Robbins GK, De Gruttola V, Snyder SW, D'Aquila RT, et al.; AIDS Clinical Trials Group 384 Team. Comparison of four-drug regimens and pairs of sequential three-drug regimens as initial therapy for HIV-1 infection. N Engl J Med. 2003;349:2304-15.

26. Department of Health and Human Services. Panel on Antiretroviral Guidelines for Adults and Adolescents. Guidelines for the use of antiretroviral agents in HIV-1 infected adults and adolescents. Baltimore: Office of AIDS Research Advisory Council; 2006. Pp.11-8.

27. Greenbaum AH, Wilson LE, Keruly JC, Moore RD, Gebo KA. Effect of age and HAART regimen on clinical response in an urban cohort of HIV-infected individuals. AIDS. 2008;22:2331-9

28. Kumarasamy N, Venkatesh KK, Devaleenol B, Poongulali S, Mothi SN, Solomon S. Safety, tolerability and effectiveness of generic HAART in HIV-infected children in South India. J Trop Pediatr. 2009;55:155-9.

29. Maneesriwongul WL, Tulathong S, Fennie $\mathrm{KP}$, Williams AB. Adherence to antiretroviral medication among HIV-positive patients in Thailand. J Acquir Immune Defic Syndr. 2006;43 (suppl 1);S119-22. 
30. Albano F, Giacomet V, De Marco G, Bruzzese E, Starace F, Guarino A. Adherence to antiretroviral therapy in children: a comparative evaluation of caregiver reports and physician judgment. AIDS Care. 2007;19:764-6.

31. Cohen MS, Chen YQ, McCauley M, Gamble T, Hosseinipour MC, Kumarasamy N, et al.; HPTN 052 Study Team. Prevention of HIV-1 infection with early antiretroviral therapy. N Engl J Med 2011;365:493-505.

32. Johnstone-Robertson S, Hargrove J, Williams B. Antiretroviral therapy initiated soon after
HIV diagnosis as standard care: potential to save lives? HIV/AIDS (Auckl). 2011; 3:9-17.

33. Cuzin L, Delpierre C, Gerard S, Massip P, Marchou B. Immunologic and clinical responses to highly active antiretroviral therapy in patients with HIV infection aged $>50$ years. Clin Infect Dis. 2007;45:654-7.

34. Guilford T, Morris d, Gray D, Venketaraman V. Atherosclerosis: pathogenesis and increased occurrence in individuals with HIV and Mycobacterium tuberculosis infection. HIV/AIDS (Auckl). 2010; 2:211-18.
35. Fernández Lisón LC, Fernández Pereira LM, Romero Chala S. Tasa de mutaciones genotípicas y resistencia a antirretrovirales en un hospital general. Farm Hosp. 2011;35:191-6.

36. Yazdanpanah Y. Costs associated with combination antiretroviral therapy in HIVinfected patients. J Antimicrob Chemother. 2004:53:558-61.

Manuscript received on 11 January 2012. Revised version accepted for publication on 9 September 2012.

RESUMEN Objetivo. Evaluar la eficacia de los tratamientos antirretrovíricos y los factores asociados con el control del $\mathrm{VIH} /$ sida en una población de pacientes tratados por el Sistema General de Seguridad Social en Salud (SGSSS) colombiano.

Eficacia del tratamiento antirretrovírico en Colombia
Métodos. Estudio descriptivo de 510 pacientes con infección por el VIH/sida que recibieron tratamiento antirretrovírico en 19 ciudades de Colombia desde junio de 1992 a abril del 2011. Se evaluaron los siguientes factores de la historia clínica de cada paciente: la carga vírica, el recuento de linfocitos CD4, las pautas de tratamiento antirretrovírico, las dosis diarias prescritas de fármacos, el tiempo de evolución de la enfermedad, la duración del tratamiento, los antecedentes de enfermedades oportunistas y los costos de los medicamentos.

Resultados. Los pacientes eran en su mayor parte varones $(75,1 \%$ frente a un $24,9 \%$ de mujeres), con una media de edad de $41,0 \pm 11,4$ años y un tiempo medio de evolución de la enfermedad de 72 meses. Todas las pautas de tratamiento recomendadas fueron prescritas a la dosis diaria definida. El tratamiento fue eficaz en $65,3 \%$ de pacientes (carga vírica $<50$ copias por $\mathrm{mL}$ ). La falta de adherencia al tratamiento, el fracaso en el tratamiento, la presencia de ansiedad o depresión y el tratamiento en la ciudad de Barranquilla se asociaron con un mayor riesgo de falta de control de la infección por el VIH. El costo promedio anual de los fármacos por paciente fue de 2736 dólares estadounidenses.

Conclusiones. Con objeto de promover soluciones para los programas de atención de salud que tratan a los pacientes con infección por el VIH/sida, se deben determinar los factores asociados con la falta de control de la infección por el VIH, especialmente en cuanto a la adherencia al tratamiento.

Palabras clave VIH; síndrome de inmunodeficiencia adquirida; terapia antirretroviral altamente activa; resultado del tratamiento; Colombia. 